\title{
Comparison of methods for determination of nutrient digestibility of a dry kibble diet for ocelots ${ }^{1}$
}

\author{
Anderson L. de Carvalho ${ }^{2 *}$, Vladimir de Oliveira ${ }^{3}$, Wanderlei de Moraes ${ }^{4}$, Zalmir S. \\ Cubas $^{4}$, Alcides R. Rinaldi ${ }^{5}$, Marcos J. de Oliveira ${ }^{4}$, Rosana. P. de Almeida ${ }^{4}$ \\ and Leonardo A.F. Bordignon ${ }^{6}$
}

\begin{abstract}
Carvalho A.L., Oliveira V., Moraes W., Cubas Z.S., Rinaldi A.R., Oliveira M.J., Almeida R.P. \& Bordignon L.A.F. 2013. Comparison of methods in the determination of nutrient digestibility of a dry kibble diet for ocelots. Pesquisa Veterinária Brasileira 33(Supl.1):7174. Hospital Veterinário, Universidade Federal do Paraná, Campus Palotina, Rua Pioneiro 2153, Palotina, PR 85950-000, Brazil. E-mail: andersoncarvalho.mv@gmail.com

In this experiment, methods of total fecal collection (TFC) and internal markers (acid-insoluble ash - AIA, crude fiber - CF, and acid-detergent fiber - ADF) were compared for determination of the coefficients of apparent digestibility (CAD) for dry matter (DM), crude protein (CP), ether extract (EE), nitrogen-free extracts (NFE), and gross energy (GE) of commercial feline dry kibble for ocelots (Leopardus pardalis). Six adult animals, weighing $12.45 \pm 1.37 \mathrm{~kg}$, gradually received experimental kibble in their usual diet until the beginning of the experiment and were submitted to an adaptation period ten days prior to the collection period. CAD obtained by TFC, AIA, CF, and ADF were, respectively, 73.7, 76.83, 62.01, and $46.03 \%$ for dry matter; $81.9,84.8,75.8$, and $63.8 \%$ for crude protein; $85,86.7,78.5$, and $69.1 \%$ for ether extract; $78.52,79.55,69.11$, and $53.04 \%$ for nitrogen-free extracts; and $80.5,82.2,71.4$, and $58.4 \%$ for gross energy. The AIA method showed to be efficient in determining coefficients of apparent digestibility and may contribute to investigations on the digestibility of diets for wild felines. In comparison to the items of ocelot's usual diet, the kibble used in this paper provided an adequate nutritional supply with reduced daily costs per animal.
\end{abstract}

INDEX TERMS: Leopardus pardalis, acid insoluble ash, crude fiber, acid detergent fiber, total fecal collection.

RESUMO.- [Comparação de métodos para estimar coeficientes de digestibilidade de uma ração comercial de gatos-domésticos para jaguatiricas.] Neste experimento foram comparados os métodos de coleta total de fezes (CT)

\footnotetext{
${ }^{1}$ Received on July 23, 2013.

Accepted for publication on November 29, 2013

${ }^{2}$ Hospital Veterinário, Universidade Federal do Paraná (UFPR), Campus Palotina, Rua Pioneiro 2153, Palotina, PR 85950-000, Brazil. *Corresponding author: andersoncarvalho.mv@gmail.com

${ }^{3}$ Departamento de Zootecnia, Universidade Federal de Santa Maria (UFSM), Avenida Roraima 1000, Bairro Camobi, Santa Maria, RS 971050900, Brazil.

${ }^{4}$ Refúgio Biológico Bela Vista, Itaipu Binacional, Rua Teresina 62, Foz do Iguaçu, PR 85870-000, Brazil.

${ }^{5}$ Programa de Pós-Graduação em Ecologia e Conservação, Setor de Ciências Biológicas, UFPR, Curitiba, PR 81531-990.

${ }^{6}$ Programa de Pós-Graduação em Zootecnia, Universidade Tecnológica Federal do Paraná, Estrada para Boa Esperança, Km 4, Dois Vizinhos, PR 85660-000, Brazil.
}

e de indicadores internos (cinza insolúvel em ácido - CIA, fibra bruta - FB e fibra em detergente ácido - FDA) na determinação dos coeficientes de digestibilidade aparente (CDA) da matéria seca (MS), proteína bruta (PB), extrato etéreo (EE), extrativo não nitrogenado (ENN) e energia bruta (EB) de uma ração comercial de gatos-domésticos para jaguatiricas (Leopardus pardalis). Seis animais adultos com peso de $12,45 \pm 1,37 \mathrm{~kg}$ receberam gradativamente a ração experimental na dieta habitual até o início do experimento e foram submetidos a um período de adaptação de 10 dias anteriores ao período de coleta. Os CDA obtidos pela CT, CIA, FB e FDA foram, respectivamente de 73,70; 76,$83 ; 62,01$ e $46,03 \%$ para matéria seca, 81,$9 ; 84,8 ; 75,8$ e $63,8 \%$ para proteína bruta, 85,$0 ; 86,7 ; 78,5$ e $69,1 \%$ para extrato etéreo, 78,52; 79,55; 69,11 e 53,04\% para extrativo não nitrogenado e de 80,5; 82,2; 71,4 e 58,4\% para energia bruta. 0 método de CIA mostrou-se eficiente na determinação dos coeficientes de digestibilidade aparente e pode 
contribuir com as investigações sobre a digestibilidade em dietas com felídeos selvagens. A ração utilizada permitiu aos animais um adequado aporte nutricional e apresentou menores custos/animal/dia em comparação aos itens que compunham a dieta habitual.

TERMOS DE INDEXAÇÃO: Leopardus pardalis, cinza insolúvel em ácido, fibra bruta, fibra em detergente ácido, coleta total.

\section{INTRODUCTION}

In the last decades, the wild population of ocelots (Leopardus pardalis Linnaeus, 1758) has drastically declined (Murray \& Gardner 1997), and one of the ways to conserve the species is keeping genetically viable ex situ populations in facilities such as wild life breeding centers and zoos (Swanson 2003, Cuarón 2005).

In the wild, L. pardalis can consume a varied diet, mainly composed of birds, mammals, and reptiles of diverse kinds and sizes (Abreu et al. 2008, Pereira-Silva et al. 2011). However, in captivity, diets are normally elaborated empirically, according to the choices and habits observed in wild animals, by trial and error and taking into account the body condition of each animal. Nevertheless, such factors may not be sufficient to attend the individual nutritional demands (Saad et al. 2007, Clauss et al. 2010).

Among the few studies on digestibility of wild felines diets, the use of raw meat or whole preys was observed. The employment of dry kibble was only studied for two species of small wild cats, Felis margarita (Crissey et al. 1997) and Felis lybica (Vester et al. 2010). For ocelots, only Bennett et al. (2009) studied the digestibility of whole preys and one type of commercial moist diet. The lack of literature data may be related to the experimental limitations mentioned by Vester et al. (2009), which highlighted the difficulty in accomplishing the experiments due to the reduced quantity of animals, as well as limitations in their handling and restraining.

The classic methodology for determination of apparent digestibility, commonly employed in domestic animals, presents high costs and requires keeping the animals in metabolic cages, for individual control of the ingested food and the total quantity eliminated as feces and urine (Oetting 2002). On the other hand, the methods of partial fecal collection (indirect) do not need metabolic cages; instead, they make use of markers in nourishment, allowing the calculation of the estimated apparent digestibility through a proportion between the ingredient and marker ingested, and the nutrient and marker that were evacuated (Sibbald 1982, Carciofi 1998, Vasconcellos et al. 2007). Among the markers used in the evaluation of digestibility of domestic cats, chromic oxide (Cr203) is the most employed (Vasconcellos 2007); nevertheless, new methods such as crude fiber (CF), acid-detergent fiber (ADF), and acid-insoluble ash (AIA) have been subject of debate (Carciofi et al. 1998, Lôbo Jr. et al 2001, Vasconcellos et al. 2007). CF and ADF correspond to the portions of the cell wall over which the digestive enzymes of mammals with undeveloped cecum are almost unable to act, therefore their assimilation relies on bacterial fermentation (Maynard et al. 1979, Sunvold et al. 1995), what allows their use as possible natural markers of digestibility for domestic cats (Carciofi et al. 1998).

Thus, the aim of this paper was to compare the use of different indirect methods for determination of the coefficients of digestibility of a commercial feline dry kibble for specimens of ocelot, and evaluate its use as an alternative diet for the species.

\section{MATERIALS AND METHODS}

Six adult ocelots weighing $12.45 \pm 1.37 \mathrm{~kg}$ were used. The animals were provided by Itaipu Binacional's wild life breeding facilities (Criadouro de Animais Silvestres da Itaipu Binacional - CASIB), Foz do Iguaçu, Paraná, Brazil, and individually sheltered in enclosures of $16 \pm 3.09 \mathrm{~m}^{2}$ with cemented floor and simple naturalization consisting of branches and trunks. The animals were fed with their usual diet (beef, chicken neck and rat), on which a gradual transition (during 25 days and exposed in Table 1) to commercial dry kibble (Royal Canin Maine Coon ${ }^{\circledR}$, Royal Canin, Brazil) was performed until it reached $100 \%$ of the diet, followed by a 10 -day adaptation period. Free access to water was provided.

The experiment was conducted in 16 days, establishing three periods of four days each and intervals of two days without collection (P1: days one to four; P2: days seven to ten; P3: days 13 to 16). The experimental diet was provided daily at 4:30 p.m., and the food waste was collected the day after at 8:00 a.m., being kept in plastic packages, identified, dried at $105^{\circ} \mathrm{C}$, and weighed in order to calculate the quantity ingested. Feces were collected daily at 8:00 a.m. and 4:00 p.m., then stored in identified plastic packages and frozen $\left(-20^{\circ} \mathrm{C}\right)$. To determine the percentage of dry matter, the samples were thawed, homogenized, and submitted to oven drying at $65^{\circ} \mathrm{C}$ and $105^{\circ} \mathrm{C}$, with subsequent ball milling. The dry samples were analyzed for crude protein (CP), ether extract (EE), crude fiber (CF), acid-detergent fiber (ADF), mineral residue (RM), and gross energy (GE), all according to the methodology proposed by Silva \& Queiroz (2002). The content of nitrogen-free extracts (NFE) was calculated through the formula NFE $=100-$ (\% moisture + \% CP + \% EE + \% CF + \% MR), while the content of acid-insoluble ash (AIA) was based on the Brazilian Textbook of Animal Nutrition (Compêndio Brasileiro de Nutrição Animal 1998).

For comparison of the coefficients of apparent digestibility (CAD), four methods were analyzed (total fecal collection - TFC, AIA, CF, and ADF), consisting of four samples per animal for each of the three periods of collection. The TFC method was used as reference. The coefficients of digestibility obtained by each method were submitted to analysis of variance and compared through Tukey's test, with significance level of 5\%, using the software Minitab 15 (Minitab Inc., USA).

Table 1. Nutritional composition and ingredients of the dry kibble used in the experiment in ocelots

\begin{tabular}{lccc}
\hline Item & Quantity & Item & Quantity \\
\hline Dry matter & $93.4 \%$ & Fibrous matter & $4.91 \%$ \\
Crude protein & $30.8 \%$ & Mineral matter & $7.4 \%$ \\
Ether extract & $23.8 \%$ & Nitrogen-free extracts & $26.49 \%$ \\
& & Gross energy & $5,028 \mathrm{Kcal} / \mathrm{Kg}$
\end{tabular}

Ingredients: chicken meal flour, isolated swine protein, rice, corn, gluten maize, wheat gluten, animal fat, borage oil, vegetable oil, fish oil, Psylliun seeds, pea-pod meal, fructo-oligo-saccharides, mannan-oligo-saccharides, beet pulp, dehydrated egg, chondroitin, glucosamine, calcium, coline, polyphenols of grape and green tea extracts, marigold extract, methionine, L-canitine, zeolite, taurine, minerals, vitamins and mineral premix, palatabilizant. 


\section{RESULTS AND DISCUSSION}

Effect of the analytical method on determination of the coefficients of digestibility

When comparing the indirect methods (CF, ADF, and AIA) to the standard method for determination of digestibility (TFC), AIA was noticed as the only one presenting data significantly similar to the TFC for all analyzed coefficients while the $\mathrm{CF}$ and ADF methods were not capable of determining them, once they underestimated such coefficients (Table 2). This information confirms Carciofi et al. (1998), Lôbo Jr. et al. (2001), and Vasconcellos et al. (2007), who verified AIA as an efficient method in this determination. Lôbo Jr. et al. (2001) reported that ADF underrated the CAD determined by total fecal collection, in contrast to Carciofi et al. (1998), who deem $\mathrm{CF}$ and $\mathrm{ADF}$ efficient in this determination, but suggest the need for new studies to confirm such conclusion. Under these conditions, the reports of Vester et al. (2008) and Clauss et al. (2010), about the likelihood of microbial fermentation in the final portion of the small intestine and in the large intestine of small felines may justify the reduced CAD estimated by $\mathrm{CF}$ and ADF in the present experiment.

Table 2. Coefficients of apparent digestibility (CAD) and standard deviation according to analysis method

\begin{tabular}{lccccc}
\hline Method & CADDM\% & CADCP\% & CADEE\% & CADNFE\% & CADGE $\%$ \\
\hline TFC & $73.7^{\mathrm{a}} \pm 7.52$ & $81.9^{\mathrm{a}} \pm 6,41$ & $85^{\mathrm{a}} \pm 4.33$ & $78.52^{\mathrm{a}} \pm 6.44$ & $80.5^{\mathrm{a}} \pm 5.95$ \\
AIA & $76.83^{\mathrm{a}} \pm 3.22$ & $84.8^{\mathrm{a}} \pm 1.92$ & $86.7^{\mathrm{a}} \pm 2.2$ & $79.55^{\mathrm{a}} \pm 5.47$ & $82.2^{\mathrm{a}} \pm 2.63$ \\
CF & $62.01^{\mathrm{b}} \pm 3.09$ & $75.8^{\mathrm{b}} \pm 3.78$ & $78.5^{\mathrm{b}} \pm 3.79$ & $69.11^{\mathrm{b}} \pm 6.52$ & $71.4^{\mathrm{b}} \pm 2.99$ \\
ADF & $46.03^{\mathrm{c}} \pm 2.5$ & $63.8^{\mathrm{c}} \pm 9.68$ & $69.1^{\mathrm{c}} \pm 6.99$ & $53.04^{\mathrm{c}} \pm 9.9$ & $58.4^{\mathrm{c}} \pm 3.42$
\end{tabular}

$\overline{\text { Different letters }}$ indicate statistical difference $(\mathrm{p}<0.05)$. CADDM $=$ coefficient of apparent digestibility for dry matter, CADCP = coefficient of apparent digestibility for crude protein, CADEE = coefficient of apparent digestibility for ether extract), CADNFE = coefficient of apparent digestibility for nitrogen-free extracts), CADGE = coefficient of apparent digestibility for gross energy.

The concentration of AIA (0.729\%) in the dry kibble of this experiment is, according to Thonney et al. (1985), subject to larger errors in the laboratorial quantification; however, the CAD results were analogous to those of TFC, validating what had already been reported by Vasconcellos et al. (2007), who used diets containing 0.11 or $0.18 \%$ of that marker and still obtained adequate determinations of CAD for all nutrients. Despite similarities, the coefficients of digestibility were slightly higher when determined by the AIA method, ranging from 1.31 to $4.25 \%$ for CADNFE and CADDM, respectively (Fig.1).

\section{Use of dry kibble as alternative diet for ocelots}

The CADDM (73.7\%) and CADCP (81.9\%) obtained in this study resembled those observed in domestic cats (Carciofi et al. 1998, Vasconcellos et al. 2007) and dogs (Lôbo Jr. et al. 2001). When compared to researches in small wild felines, the CADDM was similar to that verified by Crissey et al. (1997) in Felis margarita, yet inferior to the value found by Vester et al. (2010) in Felis lybica. In relation to the CADCP, values obtained in this study were superior to Felis margarita (Crissey et al. 1997) and inferior to Felis lybica (Vester et al. 2010).

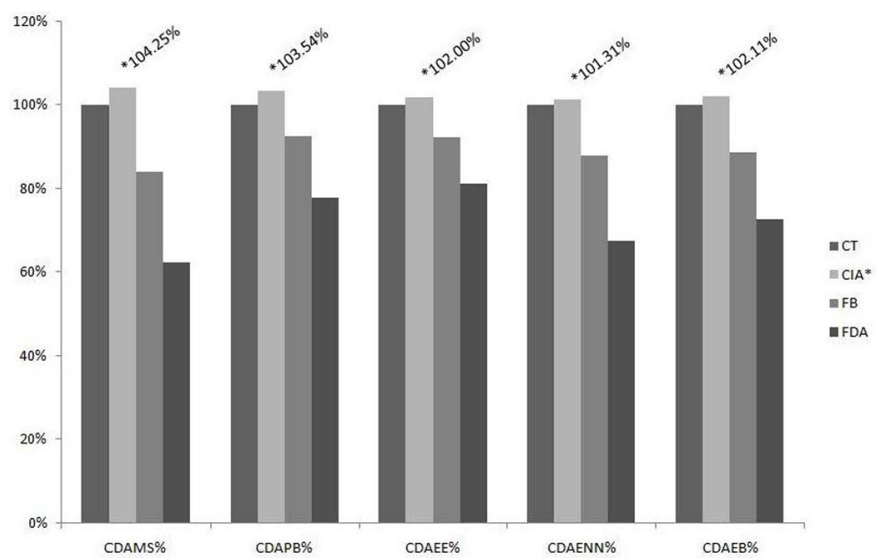

Fig.1. Comparison between the CAD estimated through the method of markers (AIA, CF, and ADF) and the CAD obtained by total fecal collection (TFC), with emphasis on the values acquired through the method of acid-insoluble ash (AIA).

The 85\% ether extract apparent digestibility was similar to Carciofi et al. (1998), Lôbo Jr. et al. (2001) and Vasconcellos et al. (2007); however, it was inferior to results obtained by Vester et al. (2010). The CADNFE observed in this study (78.52\%) was similar to the findings of Carciofi et al. (1998) and Vasconcellos et al. (2007), but smaller than the results reported by Lôbo Jr. et al. (2001). The 80.5\% CADGE was similar to Crissey et al. (1998), Lôbo Jr. et al. (2001) and Vasconcellos et al. (2007) data, but inferior to Vester et al. (2010).

In their research, Crissey et al. (1997) used specific commercial kibble for wild felines; however this diet showed to be less digestible for DM, GE, and CP when compared to raw meat. Vester et al. (2010) recommended the dry diet of their experiment, despite the fact that it presented a CADCP inferior to the standard diet. According to Crissey et al. (1997), the smaller values of nutrient digestibility found may be related to the remarkable amounts of vegetal ingredients in the experimental kibble. This was also noticed by Vester et al. (2010), who observed larger fecal volume in individuals that received dry diet, what, inclusively, demanded more time for cleaning the enclosures. In the same way, it is believed that the different species of wild felines vary in their capacity to assimilate nutrients, therefore showing the need for further evaluations concerning other types of kibbles.

In comparison to the items of ocelot's usual diet, which demands more complex facilities and specialized labor (vivaria and food manipulation), the kibble used in this experiment presented lower daily costs per animal. Nevertheless, the choice for kibbles must consider factors such as dental health (Haberstroh et al. 1984), behavior, and welfare (Bond \& Lindburg 1990), or the use of animals involved in rehabilitation programs.

\section{CONCLUSION}

Concerning dry kibble for ocelots, the use of AIA as marker was efficient for determination of the CAD for DM, CP, EE, and GE, and may be an option to the use of metabolic cages in investigations on the digestibility of diets for wild feli- 
nes once it allows the accomplishment of the experiment at the usual individual enclosure of the animal. Furthermore, commercial dry kibble, proving to be an economically viable and suitable nutritional alternative for ocelots, was properly assimilated by the species ${ }^{7}$.

${ }^{7}$ The results of this study do not necessarily reflect the views of Itaipu Binacional.

Acknowledgements.- To thank the World Nutri Alimentos para Animais Ltda for the donations of experimental kibble, and to Itaipu Binacional for allowing the use of animals, facilities, and technical support.

\section{REFERENCES}

Abreu K.C., Moro-Rios R.F., Silva-Pereira J.E., Miranda J.M.D., Jablonski E.F. \& Passos F.C. 2008. Feeding habits of ocelot (Leopardus pardalis) in Southern Brazil. Mamm. Biol. 73:407-411.

Bennett C.L., Booth-Binczik S.D. \& Steele S.R.E. 2009. Nutritional composition and digestibility by ocelots (Leopardus pardalis) of whole animals and a commercial diet. Zoo Biol. 28:1-7.

Bond J.C. \& Lindburg D.G. 1990. Carcass feeding of captive cheetahs (Acinonys jubatus): the effects of a naturalistic feeding program on oral health and psychological well-being. Appl. Anim. Behav. Sci. 26(4):373-382.

Brasil 1988. Compêndio Brasileiro de Nutrição Animal: métodos analíticos. Ministério da Agricultura e do Abastecimento, Brasília, p.199.

Carciofi A.C., Prada F. \& Mori C.S. 1998. Internal markers in the evaluation of apparent digestibility of cat feeds-method comparison. Ciência Rural 28(2):299-302.

Clauss M., Kleffner H. \& Kienzle E. 2010. Carnivorous mammals: nutrient digestibility and energy evaluation. Zoo Biol. 28:1-18.

Crissey S.D., Swanson J.A., Lintzenich B.A., Brewer B.A. \& Slifka K.A. 1997. Use of a raw meat-based diet or a dry kibble diet for sand cats (Felis margarita). J. Anim. Sci. 75:2154-2160.

Cuarón A.D. 2005. Further role of zoos in conservation: Monitoring wildlife use and the dilemma of receiving donated and confiscated animals. Zoo Biol. 24:115-124.

Haberstroh L.I., Ullrey D.E., Sikarski J.G., Richter N.A., Colmery B.H. \& Myers T.D. 1984. Diet and oral health in captive amur tigers (Panthera tigris altaica). J. Zoo Anim. Med. 15:142-146.

Lôbo Jr M.F., Rezende A.S.C., Saliba E.O.S. \& Sampaio I.B.M. 2001. Coeficientes de digestibilidade aparente pelos métodos de indicadores e coleta total de fezes em cães. Arq. Bras. Med. Vet. Zootec. 53(6):691-694.
Maynard L.A., Loosli J.K., Hintz H.F. \& Warner R.G. 1979. Animal Nutrition. $7^{\text {th }}$ ed. McGraw-Hill, New York. 602p.

Murray J.L. \& Gardner G.L. 1997. Leopardus pardalis. Mamm. Species 548:1-10.

Oetting L.L. 2002. Avaliação de diferentes marcadores para a determinação da digestibilidade e taxa de passagem do alimento em suínos. Tese de Doutorado em Ciências, Universidade de São Paulo, Piracicaba. 57p.

Saad C.E.P., Ferreira W.M., Borges F.M.O. \& Lara L.B. 2007. Avaliação nutricional de rações comerciais e semente de girassol para papagaios-verdadeiros (Amazona aestiva). Ciênc. Agrotecnol. 31(5):1493-1499.

Sibbald I.R. 1982. Measurement of bioavaliable energy in poultry feedingstuffs: a review. Can. J. Anim. Sci. 62:983-1048.

Silva D.J. \& Queiroz A.C. 2002. Análise de alimentos: métodos químicos e biológicos. $3^{\mathrm{a}}$ ed. Imprensa Universitária Universidade Federal de Viçosa, Viçosa. 235p.

Silva-Pereira J.E., Moro-Rios R.F., Bilski D.R. \& Passos F.C. 2011. Diets of three sympatric neotropical small cats: Food niche overlap and interspecies differences in prey consumption. Mamm. Biol. 76:308-312.

Sunvold G.D., Hussein H.S., Fahey Jr G.C., Merchen N.R. \& Reinhart G.A. 1995. In vitro fermentation of cellulose, beet pulp, citrus pulp, and citrus pectin using fecal inoculums from cats, dogs, horses, humans, and pigs an ruminal fluid from cattle. J. Anim. Sci. 73:3639-3648.

Swanson W.F., Johnson W.E., Cambre R.C., Citino S.B., Quigley K.B., Brousset D.M., Morais R.N., Moreira N., O’Brien S.J. \& Wildt D.E. 2003. Reproductive status of endemic felid species in Latin American zoos and implications for ex situ conservation. Zoo Biol. 22:421-441.

Thonney M.L., Duhaime D.J., Moe P.W. \& Reid J.T. 1979. Acid insoluble ash and permanganate lignin as indicators to determine digestibility of cattle rations. J. Anim. Sci. 49:1112-1116.

Vasconcellos R.S., Carciofi A.C., Oliveira L.D., Prada F. \& Pereira G.T. 2007. Utilização de indicadores para estimar a digestibilidade aparente em gatos. Arq. Bras. Med. Vet. Zootec. 59(2):466-472.

Vester B.M., Beloshapka A.N., Middelbos I.S., Burke S.L., Dikeman C.L., Simmons L.G. \& Swanson K.S. 2000. Evaluation of nutrient digestibility and fecal characteristics of exotic felids fed horse- or beef-based diets: Use of the domestic cat as a model for exotic felids. Zoo Biol. 28:1-17.

Vester B.M., Burke S.L., Dikeman C.L., Simmons L.G. \& Swanson K.S. 2008. Nutrient digestibility and fecal characteristics are different among captive exotic felids fed a beef-based raw diet. Zoo Biol. 27:126-136.

Vester B.M., Burke S.L., Liu K.J., Dikeman C.L., Simmons L.G. \& Swanson K.S. 2010. Influence of feeding raw or extruded feline diets on nutrient digestibility and nitrogen metabolism of African wildcats (Felis lybica). Zoo Biol. 28:1-11. 